\title{
Development of Student Civic Competence Through Scouting Courses as Strengthening the Young Generation Character
}

\author{
Wachid Pratomo $^{1)}$, Dwi Wijayanti ${ }^{2)}$ \\ Elementery School Teacher Study Program Universitas Sarjanawiyata Taman siswa, Indonesia ${ }^{1,2,}$ \\ putrieneliz37@gmail.com
}

\begin{abstract}
The purpose of this study Is to determine the pattern of civic competence coaching for students through Scouting Education as a reinforcement of young characters in the USSD FKIP PGIP Study Program. This study used qualitative research with a case study method. This study consists of the formulation of the problems namely: civic competence in the context of Scouting Education, Scouting learning process in fostering student civic competence, obstacles and solutions in fostering civic competence through Scouting Education, the role of Scouting Education in fostering student civic competence. In collecting data researchers used three techniques namely observation, interviews, and documentation. Data analysis uses an interactive model. This research produces several findings, namely: (1) Civic competence in the context of Scouting Education: Citizenship knowledge includes understanding democracy, understanding defending the country, understanding obligations and rights. Citizenship skills include three skills namely managerial, organizational, and scout skills. Citizenship character is in the form of character contained in the tri satya and dasa dharma. (2) Knowledge is fostered by providing the task of finding information related to Scouting to be understood and poured back on the exam, skills are fostered by learning by doing with the team system, and character is fostered by instilling the values of tri satya characters and dasa dharma with habituation and the system among. (3) Obstacles in the development of civic competence that is students still feel shy, less responsible, arriving late. The solution is to be assertive and apply reward and punishment in learning process.
\end{abstract}

Keywords: Development of Civic Competence, Scouting Education, Strengthening Character of Young Generation

\begin{abstract}
Abstrak. Tujuan penelitian ini adalah untuk mengetahui pola pembinaan civic competence mahasiswa melalui Pendidikan Kepramukaan sebagai penguatan karakter muda di Prodi PGSD FKIP UST. Penelitian ini menggunakan penelitian kualitatif dengan metode studi kasus. Penelitian ini terdiri dari rumusan masalah yaitu: civic competence dalam konteks Pendidikan Kepramukaan, proses pembelajaran Pendidikan Kepramukaan dalam membina civic competence mahasiswa, kendala dan solusi dalam pembinaan civic competence melalui Pendidikan Kepramukaan, peran Pendidikan Kepramukaan dalam membina civic competence mahasiswa. Dalam pengumpulan data peneliti menggunakan tiga teknik yaitu observasi, wawancara, dan dokumentasi. Analisis data menggunakan model interaktif. Penelitian ini menghasilkan beberapa temuan, yaitu: (1) Civic competence dalam konteks Pendidikan Kepramukaan: pengetahuan kewarganegaraan mencakup pemahaman demokrasi, pemahaman bela negara, pemahaman kewajiban dan hak. Keterampilan kewarganegaraan mencakup tiga keterampilan yaitu keterampilan manajerial, organisatorik, dan keterampilan pramuka. Karakter kewarganegaraan berwujud karakter yang terdapat dalam tri satya dan dasa dharma. (2) Pengetahuan dibina dengan memberikan tugas untuk mencari informasi terkait Kepramukaan untuk dipahami dan dituangkan kembali pada ujian, keterampilan dibina dengan learning by doing dengan sistem beregu, dan karakter dibina dengan menanamkan nilai-nilai karakter tri satya dan dasa dharma dengan pembiasaan dan sistem among. (3) Kendala dalam pembinaan civic competence yaitu mahasiswa masih merasa malu, kurang bertanggung jawab, datang terlambat. Solusi berupa bersikap tegas dan menerapkan reward and punishment dalam proses pembelajaran
\end{abstract}

Kata Kunci: Pembinaan Civic Competence, Pendidikan Kepramukaan, Penguatan Karakter Generasi Muda 


\section{INTRODUCTION}

The problem now faced by education is that learning is expected to be able to provide instructional and accompanying impacts for students and university students, it turns out more emphasis on instructional impacts only, or in the sense that only cognitive and knowledge are considered. While the impact of accompaniment received less attention, so students and university students were only cognitive aspects that were trained, for other aspects such as psychomotor and affective can be said to be ignored. This results in the absence of meaningful learning experiences.

Efforts to overcome these problems are done by fostering the dimensions of civic competence of students to have a strong character. Civic competence development can be done through education with a meaningful learning process with the Scouting Course as a compulsory subject at FKIP PGSD Study Program. Scouting courses with 2 credits in semester 1 consists of theory and practice in the form of KMD. This course is intended to equip students to have creativity so they can work in the basic fields and foster Scouting. So that students will have the competence to be able to foster Scouting activities at school as a vehicle for character building students and young generation.

This effort is to foster students so that they do not follow deviant behaviour in their daily lives. Lectures through Scouting Education courses are expected to develop student civic competence because lectures are not only in the classroom with a variety of materials but also practice in schools and communities and the students are trained to be democratic, aware of the law, responsible and skilled, critical thinking, problem-solving and cooperation.

Scouting in Indonesia has been around for a long time, in fact, it has been regulated by law namely The Constitution of The Republic of IndonesiaNumber 12 of 2010 (UU RI No 12/2010) concerning the Scout Movement. In the law, it is stated that the scout movement is based on Pancasila, so that all activities are based on Pancasila values. The Scout Movement itself as an organization has goals as regulated in article 4 UU RI No 12/2010.

The Constitution of The Republic of IndonesiaNomber12/2010 about the national education system. That the national education system is an overall component of education that is interrelated in an integrated manner to achieve national education goals. The presence of Scouting courses in tertiary institutions, especially in PGSD study programs will revive the spirit of scouting in Indonesia. Because there are still rare Scout courses in tertiary institutions, after this research it is expected that there will be other tertiary institutions that will include Scouting as subjects in their curriculum so that it will strengthen graduates with smart and good citizenship character and competence. 
In line with Megawangi (2004: 1) argues that civilization will decline if there is the demoralisation of its people. Many experts, philosophers, and wise men who say that the moral factor is the main thing must be built first in order to build an orderly, safe and prosperous society. One of the main obligations that must be carried out by parents and educators to preserve and teach moral values to our children. Moral values that are implanted will form a character which is an important foundation for the formation of a civilized and prosperous society. Of course, this is in line with the main objective of civic education. Citizenship Education contains the knowledge of citizenship based on or referring to political science, law, and citizenship. As confirmed by Winarno (2013: 117) that "material citizenship knowledge covers the fields of politics, law, and morals".

Civics are lessons that aim to form good citizens in their daily lives or in the life of the nation and state. Thus, students are expected to have personalities that are in accordance with the values of Pancasila so can create an intelligent and moral generation of people (Fauzi et al, 2013: 12-13).

Winataputra (2001: 317-318) states that the main objectives of Citizenship Education about Citizenship education in the new paradigm carries the main goal, namely developing citizenship competencies such as civil knowledge (knowledge and citizenship understood), civil disposition (values, goals, and citizenship attitudes), civil skills (sets of intellectual, social and personal citizenship skills) that should be mastered by each citizen. Scouting Education in Changing Character Education is included in extracurricular activities, as stated by Budimansyah (2010) which explains about extracurricular Scouts with PKn movers in developing national character. Scouting Education has long been character education for the younger generation. it involves tri satya, dasa dharma, and various activities carried out. In the tri satya, there are six imperatives such as those issued by Sunardi (2006: 8) including: (a) taking against the Almighty God, (b) diverting towards the Unitary State of the Republic of Indonesia, (c) opposing Pancasila, (d) sending against fellow life, (e) opposing society, (f) demanding against dasa dharma. Based on this quote, it is very clear that Scout members are designed to carry it out against God Almighty, NKRI, Pancasila, fellow life, community and dasa dharma. Religious attitudes, defence of the nation, Pancasilaism, caring, helping and building society.

\section{RESEARCH METHODS}

This type of research was a qualitative research. The data used in this study were primary data, that was the data obtained directly from research subjects. this research instrument was own research with interview guides, observations and documentation. 
Methods of data analysis by data reduction, data presentation, verification of conclusions and verification as well as checking the data validity with triangulation techniques.

\section{DISCUSSION}

Coaching civic competence of students through Scouting subjects as strengthening the character of the younger generation in the UST FKIP PGSD Study Program.

The results achieved in this study are not yet perfect because this research has only been running for one month starting from the scouting course in this semester, so the results obtained are not significant, The First, Civic knowledge or citizenship knowledge developed in Scouting Education. Based on temporary observations with Ana Fitrotunisa (lecturer supporting the course) about citizenship knowledge in Scouting Education that is related to the potential possessed by students. these potentials differ from one student to another. This potential is related to the ability to think, the ability to act, the ability to behave and an understanding of democracy. By adding citizenship knowledge in Scouting Education, it generally includes developing thoughts and knowledge about defending the country so that an attitude of love for the motherland grows understanding and mastering and implementing Pancasila values, understanding and implementing norms in society, and citizenship values such as complying with regulations and understands knowledge of democratic behaviour in families, schools, communities. Second, civic skills or citizenship skills developed and fostered through Scouting Education. The opinion of Dwi Wijayanti as one of the guiding lecturers who gave her opinion on citizenship skills in Scouting Education that there are three skills, namely managerial, organizational, and scout skills. Furthermore,citizenship skills in Scouting Education which skills related to citizens developed in Scouting Education courses are mostly participatory skills or skills for active participation. Third, civic dispositions or citizenship character in Scouting Education. Opinions expressed by Wachid Pratomo as scouting subjects give a review of the citizenship character in Scouting Education that, a character contained in the tri dharma and dharma dasa. Tri satya and dasa dharma contain 29 character values compared to 18 character values from the Ministry of Education and Culture. Each dharma contains more than one character. Based on tri satya and dasa dharma, students will be good elementary teachers and coaches. Meanwhile, according to Sumarni (18 years), the character in Scouting Education is the character of the young generation who are brave, tough, alert, resilient, independent, and disciplined. Meanwhile, according to Rosel (19 years), the character in Scouting Education includes selfdiscipline, responsibility, independence, mutual assistance, mutual cooperation, and love the environment. Based on the opinion of 
the interview results with some students in participating the Scouting Education courses, it can be concluded that Scouting Education is pious, resilient, resilient, independent, disciplined, helpful, mutual cooperation, obedient, responsible, brave, nationalism, patriotic, and skilled. All of these characters are an effort to strengthen the character of the younger generation through Scouting Education courses as agents of change who have strong characters to make changes.

The process of developing civic competence of students through Scouting subjects as a reinforcement of the character of the younger generation at UST FKIP PGSD Study Program.

The learning process that contains the pattern of civic competence coaching conducted by the UST FKIP PGIP Study Program through Scouting courses is carried out continuously, Based on findings in the field obtained by interviewing, documentation, and observation techniques related to the Scouting Education learning process in fostering student civic competence as strengthening the character of the young generation. According to Ana fitrotunisa, the learning process contains a pattern of civic competence coaching that civic competence consisting of knowledge, skills and character are jointly fostered through Scouting Education. Knowledge is hidden. in other word the importance of the activity is emphasized during Scouting exercises. The skills are carried out by method learning by doing which is carried out with a team system with the aim of causing peer tutors. Character is fostered by departing from the among the system. The lecturer in front gives a good example, in the middle of building / implementing, and behind giving encouragement. It also applies a reward and punishment system.

According to other informants, Dwi Wijayanti discussed the learning process that is very important in fostering citizenship competencies through Scouting Education for the younger generation. Knowledge is fostered through assignments to search for information related to activities in Scouting which are following the syllabus and RMP, and gather the information for the mid-term and end of semester goals. While skills are fostered through the active participation of students in each exercise in the Scouting Education course. And the last one consists of characters who are nurtured by habituation to instil character values in the tri satya and dasa dharma Scouts and apply gifts and punishment.

The next opinion was from students participating in the Scouting semester I of the UST FKIP PGIP Study Program through interviews that had been conducted. The first opinion of Susilo (18 years) revealed that the lecturer fostered skills such as ceremonies, Scout activities such as marching lines, morse, 
semapore, while characters were fostered by applying disciplinary attitudes by arriving on time, while knowledge was fostered by the task of finding news. news and information for the next lecture meeting. Meanwhile, according to Ani (18 years) revealed that the lecturer did coaching by giving good examples in words and deeds, besides that lecturers also foster a disciplined attitude of students by starting lectures at exactly 7:00. Meanwhile, according to Yoga (19 years) giving his opinion that the knowledge fostered by lecturers by giving students assignments related to the next meeting is where students have the responsibility to work on and train the brain to receive new knowledge by not forgetting old knowledge, skills by lecturers are fostered with experience directly to do, while the characters who are fostered by disciplining students to arrive on time because if you get late get punishment.

Obstacles and solutions Development of civic competence of students through Scouting courses as strengthening the character of the younger generation in the UST FKIP PGSD Study Program.

\section{Constraints}

Efforts to foster student civic competence through Scouting courses in the UST FKIP PGIP Study Program as a reinforcement of the character of the younger generation certainly cannot be separated from the obstacles faced by lecturers and students.
Researchers, in this case, find obstacles in the field faced by lecturers and students. According to Ana Fitrotunisa revealed that the obstacles in fostering student civic competence through Scouting Education are: the first, students still feel ashamed to take Scouting Education courses, especially implemented in tertiary institutions; secondly, it is very difficult for students to wear the full Scout uniforms and their attributes. This is evident starting from September the policy to use Scout uniforms when the Scouting subjects were not maximally realized.

\section{Solution}

The solution is proposed to answer the obstacles faced, as explained above, there are several obstacles faced by lecturers and students in Scouting lectures. In this sub, researchers will describe the findings obtained from interviews and observations in the field about the solutions made by lecturers to overcome the above obstacles. According to Ana Fitrotunisa, providing solutions to overcome obstacles faced in fostering student civic competence by being assertive concerning the policy of wearing.

Scout uniforms during lectures, besides having to be hard so that students are more disciplined, while also applying reward and punishment in the learning process. As well as accustoming students to discipline and provide motivation so that students are enthusiastic about attending lectures. 


\section{CONCLUSION}

Coaching of student civic competence in the UST FKIP PGSD Study Program curricularly is carried out through Scouting Education courses. The existence of these courses is a form of commitment of the Study Program to organize education and coaching the young generation through the Scouting Education program, to produce teachers who can foster the young generation through Scouting courses. The process of civic competence coaching for students through Scouting eyes does not run smoothly according to plan, there are many obstacles faced by lecturers and students. Likewise, students still consider Scouting to be a nonprestigious activity resulting in low motivation, lack of discipline, and physical health problems. The existence of Scouting courses has a positive impact, including more disciplined students, emphasis on teamwork, fostering knowledge of citizenship, citizenship skills, citizenship character, fostering spiritual competence, social competence, personal competence, competency skills, students able to self development,community development, and unit development.

\section{REFERENCES}

[1] Budimansyah, D. (2010). Penguatan Pendidikan Kewarganegaraan untuk Membangun Karakter Bangsa. Bandung: Widya Aksara Press.

[2] Fauzi dkk (2013) Peran Guru Pendidikan Pancasila dan Kewarganegaraan dalam Upaya Pembentukan Karakter Peserta Didik.
Jurnal PPKn UNJ Online, Volume I, Nomor 2, Tahun 2013

[3] Megawangi, R. (2004). Pendidikan Karakter: Solusi yang Tepat Untuk Membangun Bangsa. Jakarta: BPMigas.

[4] Sunardi, A. (2006). Boyman Ragam Latih Pramuka. Bandung: Nuansa Muda.

[5] Undang-Undang Republik Indonesia Nomor 12 Tahun 2010 Tentang Gerakan Pramuka.

[6] Undang-Undang Republik Indonesia Nomor 20 Tahun 2003 Tentang Sistem Pendidikan Nasional.

[7] Winarno. (2012). Pembelajaran Pendidikan Kewarganegaraan (Isi, Strategi, dan Penilaian. Jakarta: Bumi Aksara.

[8] Winataputra, U, S. (2001). Jatidiri Pendidikan Kewarganegaraan sebagai Wahana Pendidikan Demokrasi. (Disertasi). Sekolah Pascasarjana, Universitas 